シンポジュウム：気管呼吸者の管理

\title{
長期人工呼吸患者の管理
}

$\begin{array}{cccc}\text { *天 } & \text { 羽 } & \text { 敬 } & \text { 祐 } \\ \text { 中 } & \text { 村 } & \text { 康 } & \text { 之 }\end{array}$

\section{Managements of the Patient under long term Ventilator treatment}

\author{
Keisuke Amoo, M. D., et al. \\ Department of Anesthesiology, Yokohama city University
}

For the last ten years, there has been a remarkable progress in the artificial ventilator treatment in every field in the hospital, so that a long term artificial ventilation is now practical and indication for it has expanded in numbers of diseases. Concurrently, many problems inherent to it have appeared in front.

These problems consist of two parts. First problem is concerned with a choice of the most suitable measure to secure the airway of the patient with respiratory failure. Measures include orc-endotracheal, naso-endotracheal intubation and tracheostomy. They should be evaluated in terms of the followings : promptness and risk in establishing them, how long they will be needed, easiness in fixing the tubes in right position, and in maintaining them patent and clean, probable difficulties encountered when discontinuing or re-establishing them and comfort of the patient. Needless to mention, misplased or occuluded tubes in the trachea can be lethal. Therefore, once the patient is intubated, whatever the measure might be, frequent and close observation is mandatory.

Second problem is concerned with humidification of the airway. Intubation, bypassing the physiological humidifying apparatus, i.e. the upper respiratory tract, causes drying out the mucus membrane of the lower respiratory tract which leads to the depressed function of the cilia. This in turn leads to accumulation of sputum in the periphery of the lungs, then the lungs tend to become afelectatic and are rendered to get infected. So, the humidity must be supplemented by a humidifier or a nebulizer. Frequent suctioning in the trachea with a catheter in order to fascilitate excretion of the sputum is also mandatory, Unfortunately, it is painstaking to do the tracheal suction in an aseptic way. Besides, the most common cause of death of the patient under long term artificial ventiltion is pulmonary infection. To gain specimen of tracheal aspirate for organism to culture and to take chest film once evervday if possible, are the recommended measures prevent or find the infection in early stage.

\footnotetext{
*横浜市立大学医学部

麻酔学教室
} 


\section{はじめに}

最近10年間における人工呼吸療法は各科領域 においてめ゙ざしい発展をみせており，その適 応範囲は今後もますます应がつていくものと思 われる。以前, 人工呼吸といえば，專ら死に瀕 した重症患者の死亡宣告前の一つのセレモニ一 のように過ぎないことも多かつた。しかし，近 年人工呼吸の生体に及ぼす好影響が次第に解明 されるにつれ，治療的ないし予防的な手段とし て人工呼吸が日常臨床でしばしば用いられるよ うになつた。その結果, 最近では比較的長期間 にわたつて人工呼吸を行なら症例がふえ, それ に附随したいろいろの問題が注目されるように なつた。

本稿ではわれわれの経験した症例を中心に長 期人工呼吸中の患者の気道管理に関する問題に ついて概説したい。

\section{気道確保の問題}

長期人工呼吸に際して一つの重要な問題点は 気道確保とそれに伴う合併症である。気道確保 は以前は主に気管切開によることが多かつた が，近年では気管内挿管による方法が用いられ ることも多い。

表 1

長期人工呼吸患者の気道確保

\begin{tabular}{|c|c|c|c|c|}
\hline 方法 と & と 時 期 & 症例数 & 総 計 & 平均治療日数 \\
\hline \multirow{2}{*}{ 気管切開 } & 人工呼吸前 & 48 & \multirow{2}{*}{92} & \multirow{2}{*}{5.9} \\
\hline & 人工呼吸中 & 44 & & \\
\hline \multirow{2}{*}{ 気管内插管 } & 経 口 的 & 18 & \multirow{2}{*}{40} & \multirow{2}{*}{2.3} \\
\hline & 程 鼻 的 & 22 & & \\
\hline
\end{tabular}

たとえば表 1 はわれわれが経験した長期人工 呼吸（12時間以上連続して行なつた場合）の症 例 132 例について, 気道確保の方法を調べたも

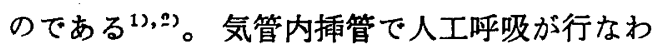
れたのはほほ $1 / 3$ の症例で, 他はいつれかか時 期に気管切開が行なわれている。気管内挿管で は経口的と経鼻的が行なわれ, 経鼻的に行なつ たものがやや多かつた。

これら気道確保の方法にはそれぞれの得失利
害があり，個々の症例によつていずれの方法を 潠択するかが決められる。

以前は急性の呼吸不全患者に対しては気管切 開がまず考えられたが，最近では気管内挿管が まず行なわれるべき気道確保の祭急処置とされ ている。気管内挿管の安全, 迅速, 容易さなど を比べれば，その優劣はおのずから明らかであ る。

しかし気管内㧌管によつて長期の人工呼吸を 行なう場合には，つねにチューブの狭窄や閉塞 の危険があり, 気道内分泌物の吸引は気管切開 に比べると容易ではなく，また患者に与える苦 痛も少なくない。したがつて人工呼吸が大体 48 時間を超えて長期に及ぶときは気管切開を行な うのが一般的な原則である。

たとえば表 1 にみられるごとく，気管切開を 通じて人工呼吸を行なつたときの平均治療日数 は5.9日で，搟管して行なつたときは平均2.3日 で，2日をこえて人工呼吸が行なわれるときは 気管切開が用いられている。

しかし幼小児に対しての人工呼吸は別で, 気 管切開はその技術的困難さ, 気胸, 感染などの 一次的合併症の他に, 気管カニウレの抜去困難 症, 気管狭窄などの問題もあり, 長期人工呼吸 の手段として必ずしも理想的なものとはいえな い。

そのため最近では気管切開に代つて経鼻的な 気管内插管に上る気道確保が幼小児に対して広 く行なわれるようになつた ${ }^{3), 4 。 ~}$ 。経鼻的気管内 插管は気管切開のように手術操作に伴う危険や カニューレ除去時の障害などが少なく, 経口挿 管に比べると患者への苦痛も少ない。また必要 に応じていつでも気管切開を行なうことができ る。この方法によれば大体 $2 \sim 3$ 週間は大きな 合併症を伴なわずに気道確保ができるといわれ る。このように経鼻插管法が繁用されるように なつた一つの理由は, 生物化学的に活性 が 低 く, 組織の炎症性反応が少ない, 柔軟で可塑性 のある気管内チューブ Portex tube (Polyvinyl chloride）が開発されたことにもよる。

経口でも経鼻でも, 気管内捅管によつて気道 確保が行なわれた場合には，チューブの固定を できるだけ確実にすることが大切である。 


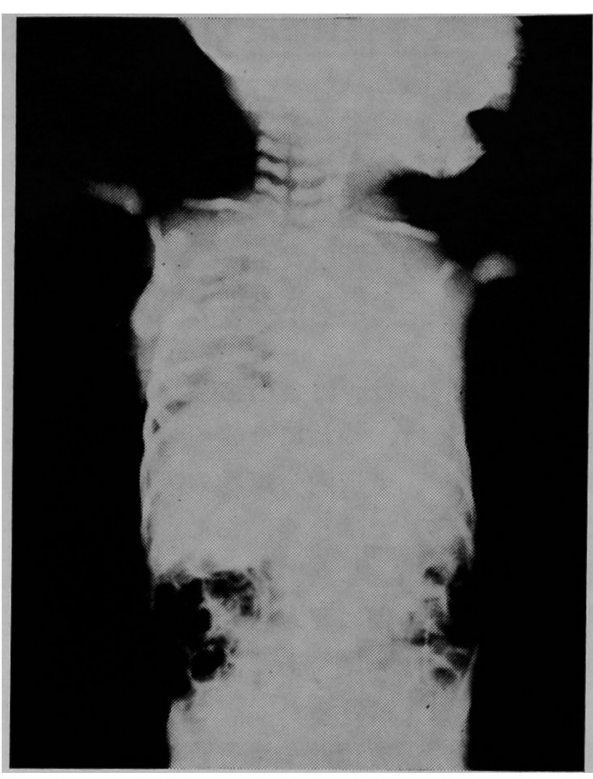

(a)

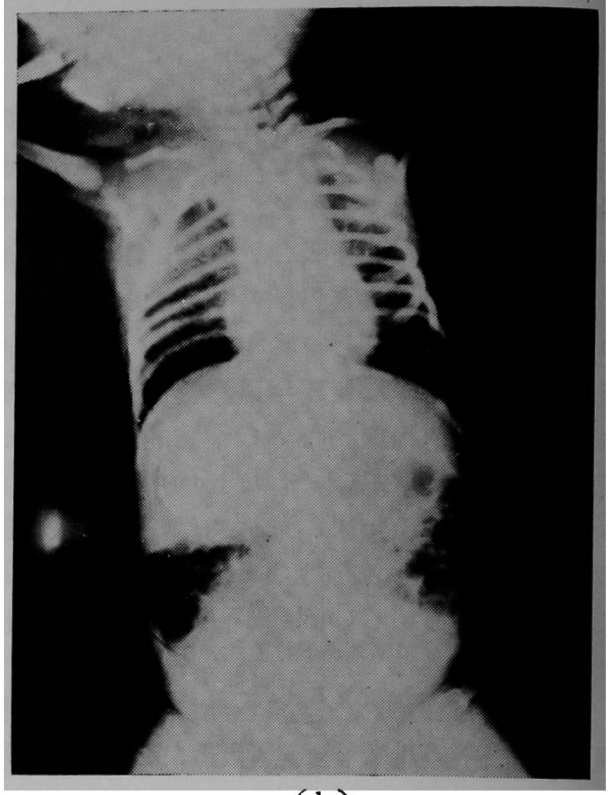

(b)

図1気管内チューブの移動による一側肺のアテレクターゼ

図 1 は術後呼吸不全に陥入つた新生児に気管 内插管により人工呼吸を行なつた症例である。 固定が悪かつたために治療中にチューブが気管 内に徐々に深く入り，その先端が右気管支に入 つたため左側の肺全体が完全な atelectasis とな つている（図 $1 \mathrm{a}$ )。チューブを引きもどして肺 内に十分な圧をかけた結果 atelectasis は消失し 両側の肺は再び㧪がつている（図 $1 \mathrm{~b}$ )。

気管内チューブを介して人工呼吸を行なつて いるときは，この他にチューブ内に分泌物が詰 つたりチューブの屈折などにより気道の狭窄や 閉塞をきたすことがしばしば起る。とくに幼小 児の場合には使用するチューブの内腔がせまい ので, 気道分泌物が多量のときにはそれで容易 にチューブが詰まり重大な事故を惹起すること になる。

気管内に插管された一本のチューブは人工呼 吸中の患者にとつてはまさに命の綱であり, そ こに起つた変化はたとえ些細なことでも, 忽ち 患者を死に追いやることになる。したがつて人 工呼吸中の患者にはどんな僅かな変化に対して も細心の注意を払つて観察し事故を未然に防が なければならない。そのためには呼吸パター
ン，胸廓の動き，気道内圧，換気量などを定期 的に意りなくチェックする必要がある。

\section{給湿と吸引の問題}

気管切開にせよ気道内插管にせよ,こうした チューブを介して人工呼吸を行なつている患者 では, 吸気に適度の湿度を与える生理学的な給 湿器官がバイパスされており，しかも割合に大 きな換気量が用いられているために，下部の気 道だけでは吸気に十分な湿度を与えることがて きない。そのため人工呼吸中の患者は，おおむ 故その気道が非常に乾燥しやすい状態にある。

気道内面を被う繊毛 (Cilia) には二層の粘液 層がある。これが Cilia の動きでちようどべル トコンベアーのように働き気道の分泌物や異物 を口側へと運んでいる（図 2 ）。繊毛運動はま た温度によつても影響され，粘膜の温度がある 程度以下になると運動は停止する。人工呼吸中 の患者では比較的低温の吸気が直接気道に入る ため, 気道粘膜は正常以下の温度になり易い。

気道の乾燥と低温ということから，人工呼吸 中の患者では繊毛運動が障害され，正常なメか ニズムによる喀凖排泄能は著しく阻害されてい 


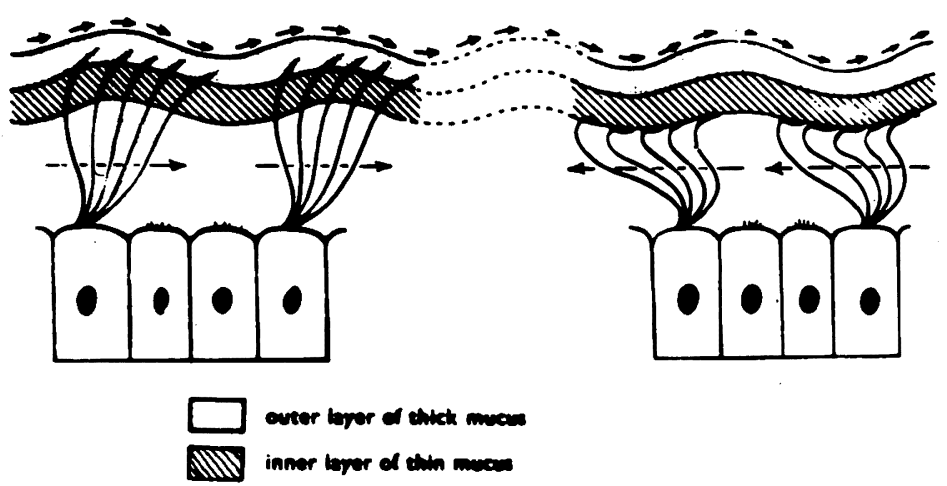

図 2 気道の㵶毛運動

るのが通例である。その結果, 気道の分泌物は 停滞固結し, 気道の狭窄, 閉塞から無気肺, さ らに肺炎という事態に到ることがある。

したがつて人工呼吸中の患者では吸引によつ て分泌物をとり除いてやることが，とくに分泌 物の多い患者では非常に大切な操作である。吸 引の回数は症例によって異るが, 分泌物が多い ときは10分おきぐらいに吸引を必要とすること もある。ただ吸引操作は手際よく迅速に行なう ことが肝要である。吸引は分必物をとり除くと 同時に, 肺内のガスも急激に吸引しまた好まし くない反射を催起したりする。したがつて拙劣 な吸引操作は患者を急激な低酸素血症に陥し入 れる危険があり，一回の吸引は少なくとも15秒 以内に行なうべきである。また患者の状態によ つては吸引前に純酸素を与えて血中の酸素分圧 を高めておくなどの考虑が必要である。

吸引操作と平行して大切なことは, 吸気に適 度な湿度を与えることである。十分な給湿を行 なうことは喀痰排泄能を維持し, 肺感染を防止 するためにも必ず行なわれなければならない。 そのため現在使用されている長期人工呼吸用の レスピレーターには必ず何らかの給湿装置が備 えてある。

給湿装置にもいろいろの考案があり，たとえ ば薄いアルミはくをぐるぐる巻いて筒の中に入 れた人工鼻 (artificial nose) を呼吸回路内にお き, 呼気中の湿り気をここにつけ吸気の給湿に 利用するものむある。この他, 吸気を水や湯の 中を通して湿度を与える Humidifier も多く使
われている。しかしこうした給湿方法では，た とえば脱水や高熱を有する患者では水分補給が まだ不十分でもつと吸気中に湿度を必要とする ことがある。

そこで Nebulizer でキリを作つて積極的に吸 気に湿度を与えることも行なわれている。

気道内に吸い込まれたキリの粒子はその大き さによつて気道の異なつた場所に沈着する。た とえば気道末梢の肺胞レベルにまでキリが到達 するには 3 ミクロン前後の粒子の大きさが最も 適している。しかし10ミクロン以上の粒子では その大部分が上気道に沈着して末梢には極めて 僅かしか到達できない。

近年新らしい型の給湿器官として Ultrasonic Nebulizer が各科領域で広く用いられている ${ }^{5)}$ 。 この原理は約 3 メガサイクルで振動する板上に 水滴を落してキリを作るもので，この粒子は大 体 3 ミクロン前後のものが最も多い。したがつ て肺胞へベルにまで粒子がとどき極きて有効な 給湿ができるといわれる。しかも点滴の早さを 加減することによつてキリの量が調節できるわ けである。

この Nebulizer は確かに従来のものに比べる といくつかのすぐれた点をもつており, 各方面 で使用される機会がふえている。しかしその反 面この Nebulizer 使用に伴う障害もいくつか報

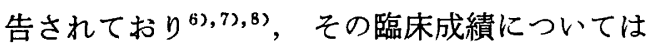
必ずしも好結果ではなく, 今後の研究に待つ所 も多いと思われる。 


\section{気道感染の問題}

人工呼吸中は正常な除塺装置がないこと，ま た人工呼吸器回路内は高湿度, 高酸素濃度とい う環境下のため, 容易に肺の感染が起る。

人口呼吸開始後 3 日目の患者 31 名について気 道分泌物艺培養してみると表 2 のような結果を 得た。Pseudomonas, Staphylococcus, Streptoc occus が非常に多く, Esherichia Coli; の検出 も一名に認められた。気道看護には無菌的な操
表 2 気道内分泌物の培養結果

\begin{tabular}{l}
\hline Psudomonas pyocyaneus $\ldots \ldots \ldots \ldots \ldots \ldots \ldots \ldots \ldots 11$ \\
Staphlococcus pyogenes $\ldots \ldots \ldots \ldots \ldots \ldots \ldots \ldots \ldots \ldots$
\end{tabular}

表 3 Principal Causes of Death during Respirator Treatment

\begin{tabular}{|c|c|c|c|c|c|c|c|c|c|c|c|c|}
\hline $\begin{array}{l}\text { Day of Treatment } \\
\text { Diseases }\end{array}$ & 1 & 2 & 3 & 4 & 5 & 6 & 7 & 8 & 9 & 10 & $11<$ & Total \\
\hline Pneumonia & & 3 & 4 & 3 & 2 & 2 & 1 & & 1 & & 4 & 20 \\
\hline Acute Heart Failure & 5 & 2 & 1 & 1 & & 1 & & & & 1 & & 11 \\
\hline Hemorrhage & 4 & 2 & & & & & & & & & & 6 \\
\hline Renal Tubular Necrosis & 1 & 1 & 2 & & 1 & 1 & & & & 1 & & 7 \\
\hline Myocard Infarct & 2 & 2 & & 1 & & & & & & & 1 & 6 \\
\hline Brain Damage & 1 & 1 & & & & & 1 & & & & & 3 \\
\hline Total Bowel Gangrene & & 1 & & 1 & & & & & & & & 2 \\
\hline Pulmonary Embolus & 1 & 1 & & 1 & & & & & & & & 3 \\
\hline Cerebral Thrombosis & & 1 & & 1 & & & & & & & & 2 \\
\hline Respirator Accident & & & 1 & & 1 & & & & & & & 2 \\
\hline Causes undetermined & 1 & 1 & & 1 & 1 & 1 & 1 & & 1 & & & 7 \\
\hline Total & 15 & 13 & 9 & 9 & 5 & 5 & 3 & 0 & 2 & 2 & 5 & 53 \\
\hline
\end{tabular}

作がとくに重要と思われる。

表 3 は人工呼吸治療中に死亡した 53 症例の主 な死因を調べたものである。もちろん長期にわ たつて人工呼吸を必要とするような重症患者で はいくつもの直接または間接的な死因が混在し ていることが多いが，この表は患者の死に最も 関係が深いと考えられた原因のみをとりあげた もので, このうち39例は剖検例で他は臨床的判 定によるものである。

肺炎が最も多く20例で死因の約38\%を占めて いる。しかし主な死因ではないまでも肺に何ら かの感染が認められたものを含めれば，39例の 剖検中32例に肺感染の所見が認められている。 この事実は肺の感染防止が患者の予後にとつて
いかに重要であり，またその防止が実際いかに 困難であるかを示唆するものであろう。人工呼 吸中の患者では吸引やその他の操作をできるか ぎり無菌的に行ない, 定期的な喀痰の培養や胸 部レ線撮影を行ない感染の予防と対策に十分留 意する必要がある。

\section{文献}

1）天羽敬祐：長期人工呼吸の臨床と研究一第一編 内科系呼吸不全患者の治療一麻酔 $16: 952$, 昭 42

2) 天羽敬祐 : 長期人工呼吸の臨朱と研究一第二編 外科系呼吸不全患者の治療一麻酔16:1048, 昭42

3) Allen, T.H.et al : Prolonged endotracheal in. tubation in infants and children. Brit. J. Anaesth. 37: 556, 1956.

4) Markham, W. C. et al: Prolonged nasotracheal] intubationin in infants and children. Canad. Anae- 
sth. Soc. J. 14: 11, 1967.

5) Herzog, P. et al : Ultrasonic generation of aerosol for the humidification of inspired gas during volume-controlled respiration. Acta Anaesth.Scardinav. 8: 79, 1964.

6) Reinarz, J.A. : et al : The potential role of inhalation therapy equipment in nosocomical pu-
Imonary infection. J. Clin. lnvest. 44: 831,1965.

7) Modell, J. H. et al: Effect of chronic exposure to ultrasonic aerosol on the lung. Anesthesiology 28: 680, 1967.

8) Avery, M. E., et al: Mist therapy. Pediatrics 39: $160,1967$.

\section{気管支造影剤}

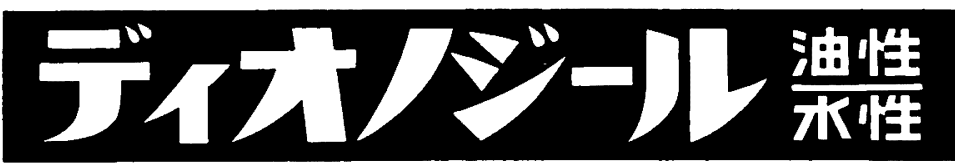

特展

- きわめて鮮明な影像が得られる

○吸収がく24時間後には局所から 任とんど消失する

・注入は容易で刺激作用を認めない

包菬

油性・水性 $15 \mathrm{ml} 60 \mathrm{ml}$ パイアル入

$$
57-9
$$

\section{莱価基淘}

（水性） 50\% $1 \mathrm{ml} 39.00$ 円

（油性） $60 \% 1 \mathrm{ml} \mathrm{39.00円}$

\section{促保通用}

造元 グラクソ不二蒋品研究所

販売促進 インターボョナル・ドラッグッレス

発壳元裹居菜品株式会社 